
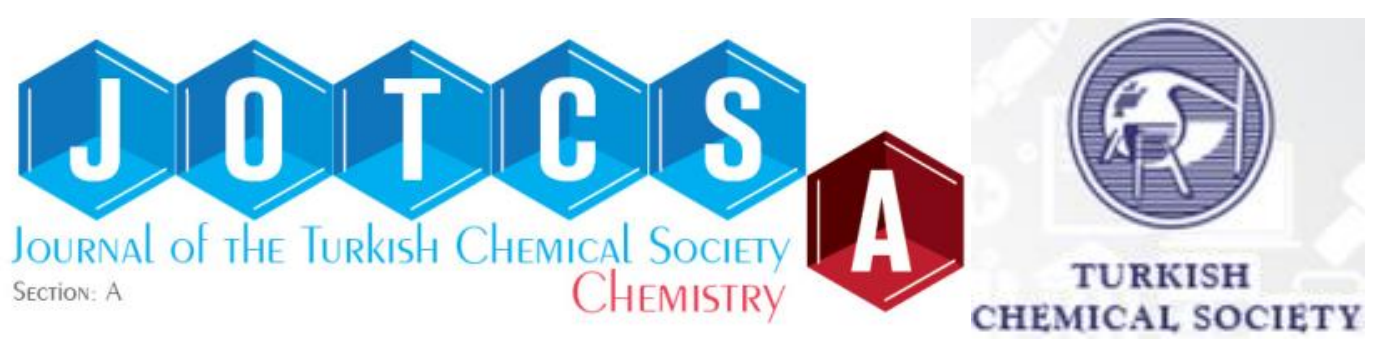

\title{
Synthesis, Molecular Structure, Hirshfeld Surface Analysis, Spectroscopic and Computational Studies (DFT) of 6,6'-((1E,1'E)- (1,2-phenylenebis(azanylylidene))bis(methanylylidene))bis(2- (tert-butyl)-4-methylphenol)
}

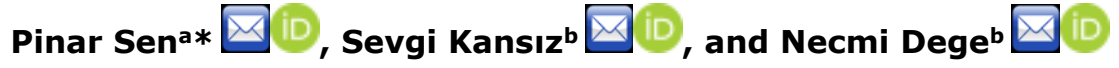 \\ ${ }^{a}$ Centre for Nanotechnology Innovation, Department of Chemistry, Rhodes University, Grahamstown, \\ 6140, South Africa \\ bOndokuz Mayıs University, Faculty of Arts and Sciences, Department of Physics, 55139 Samsun, \\ Turkey
}

Abstract: Schiff bases have been used in biological processes and as chelating agents for several decades. In this work, a Schiff base compound was obtained with the condensation of ophenylenediamine and an aromatic aldehyde. The structures were confirmed by spectroscopic methods. The molecular structure of the compound was also confirmed using X-ray single-crystal data. And also we made the parameters calculate theoretically the DFT-B3LYP method. For $\mathrm{C}_{30} \mathrm{H}_{36} \mathrm{~N}_{2} \mathrm{O}_{2}$ compound, HOMO-LUMO and MEP surface were composed by making use of $\mathrm{C}_{30} \mathrm{H}_{36} \mathrm{~N}_{2} \mathrm{O}_{2}$. The theoretical results are in a good concurrence with the empirical values. To analyze interactions existing in crystal packing, 2D fingerprint plots and Hirshfeld surface analyses were performed, signifying that the contributions are $\mathrm{H} \cdots \mathrm{H}(71.2 \%), \mathrm{H} \cdots \mathrm{C} / \mathrm{C} \cdots \mathrm{H}(18.7 \%)$ and $\mathrm{C} \cdots \mathrm{C}(4.8 \%)$ contacts.

Keywords: Synthesis, crystal structure, Schiff base, theoretical calculation, DFT, HOMO-LUMO, MEP, FT-IR, NMR, Hirshfeld surface.

Submitted: November 15, 2018. Accepted: April 08, 2019.

Cite this: Şen P, Kansız S, Dege N. Synthesis, Molecular Structure, Hirshfeld Surface Analysis, Spectroscopic and Computational Studies (DFT) of 6,6'-((1E,1'E)-(1,2-

phenylenebis(azanylylidene))bis(methanylylidene))bis(2-(tert-butyl)-4-methylphenol). JOTCSA. 2019;6(2):189-200.

DOI: https://dx.doi.org/10.18596/jotcsa.483143.

*Corresponding Author. E-mail address: sen pinar@hotmail.com.

\section{INTRODUCTION}

Schiff bases are an essential class among organic compounds (1). Schiff bases, having the $\mathrm{C}=\mathrm{N}$ linkage, have been extensively studied as azomethine derivatives and they have chelating structure. These kind of ligands have drawn attention largely since they have anticancer and antibacterial activities in biological processes (2). One of the key application areas of Schiff's bases is that they are also used as corrosion inhibitors (3).
Schiff base ligands coordinate the transition metals to form stable complexes (4). Schiff base metal complexes, which exhibit interesting physical and chemical properties, have wide range of usage in diverse areas of science (5).

Metal complexes of Schiff base exhibit catalytic performance in different organic reactions besides uses in polymer and dyes industry (6). They exhibit biological activity as antibiotic, antiviral and antitumor agents (7). They are also used as antifertility and enzymatic agents (8). 
Some Schiff base complexes have been formed with the reaction of an aldehyde derivative and aromatic diamine and the obtained this kind of structures showed more rigidity. They have been found to be used in a variety of systems showing good catalytic activity (9).

Accordingly, we achieved a type of imine compound by the reaction of o-phenylenediamine and an aldehyde compound to give $\mathrm{N}, \mathrm{N}^{\prime}$-bis(3tert-butyl-5-methylsalicylidene)-1,2-

diaminobenzene.

We aimed to see the effect on the spectroscopic properties of this rigid structured Schiff base obtained by the aromatic diamine compound. Also, tert-butyl groups were chosen in order to improve the solubility of the compound in organic solvents unlike the samples that were previously worked.

Although this molecule (2) was previously published as a molecular crystal structure (10), we have enriched the work by performing all characterizations and additionally theoretical calculations with investigating HOMO-LUMO energies, MEP surface map, and analysis of Hirshfeld surface. For the calculations of the geometrical structure of $\mathrm{C}_{30} \mathrm{H}_{36} \mathrm{~N}_{2} \mathrm{O}_{2}, 6-31 \mathrm{G}(\mathrm{d}, \mathrm{p})$ base set with DFT methods were performed.

\section{EXPERIMENTAL}

\section{Chemicals and instruments}

The following chemicals were obtained from Sigma-Aldrich: 2-tert-butyl-4-methylphenol, urotropin, glacial acetic acid, ophenylenediamine, dichloromethane (DCM), chloroform $\left(\mathrm{CHCl}_{3}\right)$, diethylether, methanol $(\mathrm{MeOH})$, ethanol (EtOH), and acetone. All solvents were dried and purified as described by Perrin and Armarego (11). Thin-layer chromatography (TLC) based on silica gel 60$\mathrm{HF}_{254}$ was utilized. Perkin Elmer Spectrum Two FT-IR Spectrometer was used to record the infrared spectra. ${ }^{1} \mathrm{H}$ and ${ }^{13} \mathrm{C}$ NMR spectra were obtained with Varian Mercury Plus $300 \mathrm{MHz}$ spectrometer. Mass analysis was performed on an Agilent 6230 A LC-TOF/MS spectrometer. The elemental compositions of the samples were determined by Flash 2000 by Thermo Scientific.

\section{Synthesis \\ 3-tert-butyl-2-hydroxy-5- methylbenzaldehyde (1)}

The preparation of $\mathbf{1}$ was performed by applying a literature procedure. The spectroscopic data obtained are as expected (12).

\section{Synthesis of $N, N^{\prime}$-Bis(3-tert-butyl-5- methylsalicylidene) -1,2-diaminobenzene (2)}

The o-phenylenediamine $(140,6 \mathrm{mg}, 1.3 \mathrm{mmol})$ solution in methanol ( $30 \mathrm{~mL})$ was added to solution of 3-tert-butyl-2-hydroxy-5methylbenzaldehyde (1) (500 mg, $2.6 \mathrm{mmol})$ in methanol $(30 \mathrm{~mL})$. The reaction mixture was degassed by argon-vacuum system at room temperature and the temperature brought to reflux temperature for $12 \mathrm{~h}$. The reaction was controlled by TLC. After the reaction was completed, the temperature of the mixture was allowed to reach room temperature. The precipitated Schiff base was separated from the solution by filtration and washed with methanol and diethyl ether. The resulting product were recrystallized from methanol and dried to give the desired pure product as orange-colored crystals. Yield: 52\% (308 mg). FT-IR (UATR) $\vee \mathrm{max} / \mathrm{cm}^{-1}$ : 3060 (Ar, C-H), 2994-2857 (aliph., C-H), 1613 $(\mathrm{C}=\mathrm{N}), 1567(\mathrm{Ar}, \mathrm{C}=\mathrm{C}), 1482-1388$ (aliph., C-C), $1209,1164,748 .{ }^{1} \mathrm{H}-\mathrm{NMR}\left(\mathrm{CDCl}_{3}\right) \delta(\mathrm{ppm}): 13.50$ $(\mathrm{s}, 2 \mathrm{H}), 8.61(\mathrm{~s}, 2 \mathrm{H}), 7.32-7.29(\mathrm{~m}, 2 \mathrm{H}), 7.23-$ $7.21(\mathrm{~m}, 2 \mathrm{H}), 7.18(\mathrm{~d}, 2 \mathrm{H}), 7.03(\mathrm{~s}, 2 \mathrm{H}), 2.29(\mathrm{~s}$, $6 \mathrm{H}), 1.42(\mathrm{~s}, 18 \mathrm{H}) .{ }^{13} \mathrm{C}-\mathrm{NMR}\left(\mathrm{CDCl}_{3}\right) \delta(\mathrm{ppm})$ : $164.61,158.81,142.69,137.79,131.90,130.69$, $127.59,127.09,120.19,119.04,35.05,29.60$, 20.89. MS : $\mathrm{m} / \mathrm{z} 457.867(\mathrm{M}+1)^{+}$. Anal. Calc. for $\mathrm{C}_{30} \mathrm{H}_{36} \mathrm{~N}_{2} \mathrm{O} 2(\%): \mathrm{C}, 78.91 ; \mathrm{H}, 7.95 ; \mathrm{N}, 6.13 ; \mathrm{O}$, 7.01; Found (\%): C, 78.72; H, 7.99; N, 6.09; O, 7.07 .

\section{RESULTS and DISCUSSION}<smiles>Cc1ccc(O)c(C(C)(C)C)c1</smiles><smiles>Cc1cc(C=O)c(O)c(C(C)(C)C)c1</smiles>

1

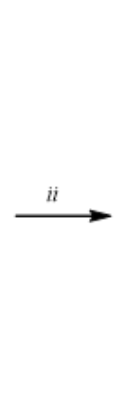<smiles>Cc1cc(C#N)c(O)c(C(C)(C)C)c1</smiles>

2

Scheme 1. Synthetic route: (i) glacial $\mathrm{CH}_{3} \mathrm{COOH}$, urotropin, $120^{\circ} \mathrm{C}$ (ii) o-phenylenediamine, methanol.

As a first step, 3-tert-butyl-2-hydroxy-5methylbenzaldehyde (1) was obtained by reacting of commercially available 2-tert- butyl-4-methylphenol with urotropin in glacial $\mathrm{CH}_{3} \mathrm{COOH}$ using the literature procedure (Duff reaction is one of the most convenient 
preparation methods for ortho-hydroxy substituted aromatic aldehydes) (12). In the second step, the Schiff-base ligand (2) was achieved by the condensation reaction between the aldehyde derivative (1) and commercially available o-phenylenediamine in anhydrous methanol at reflux temperature as exhibited in Scheme 1.

The structural characterization of the synthesized products was elucidated by several spectroscopic methods such as ${ }^{1} \mathrm{H}-$ NMR, ${ }^{13} \mathrm{C}-\mathrm{NMR}$, FT-IR, mass spectrometry and also by elemental analyses. All the spectral data showed the expected results.

In the FT-IR spectrum of $\mathbf{2}$, the structure of Schiff base was confirmed by the disappearance of the carbonyl band at 1645 $\mathrm{cm}^{-1}$ and the $\mathrm{C}-\mathrm{H}$ bands of aldehyde group at $2895 \mathrm{~cm}^{-1}$ and $2773 \mathrm{~cm}^{-1}$ originating from 1 and the appearance of $-\mathrm{C}=\mathrm{N}$ vibration band at
$1613 \mathrm{~cm}^{-1}$ indicating the condensation to give 2.

The ${ }^{1} \mathrm{H}-\mathrm{NMR}$ data presented decisive results about the introduced molecules. When investigated the ${ }^{1} \mathrm{H}-\mathrm{NMR}$ spectra of compound $\mathbf{1}$ and 2, the disappearances of $\mathrm{HC}=\mathrm{O}$ proton signal of $\mathbf{1}$ and the presence of new aromatic peaks at $8.61 \mathrm{ppm}$ belongs to the imine protons are the evidence that the imine condensation reaction has occurred. The other characteristic peak was observed at 7.32-7.21 ppm related to phenylene group of $\mathbf{2}$.

When the ${ }^{13} \mathrm{C}-\mathrm{NMR}$ spectrum for $\mathbf{2}$ is taken into account, the existence of the signals at 164.61 ppm belonging to the carbon atom of the imine group and new aromatic peaks, are obviously different from 1. In the MS spectrum of $\mathbf{2}$, the molecular ion peak revealed at $\mathrm{m} / \mathrm{z}$ : 457.867 $(M+1)^{+}$as intensive obviously demonstrate the generation of expected product as exhibited in Figure 1.

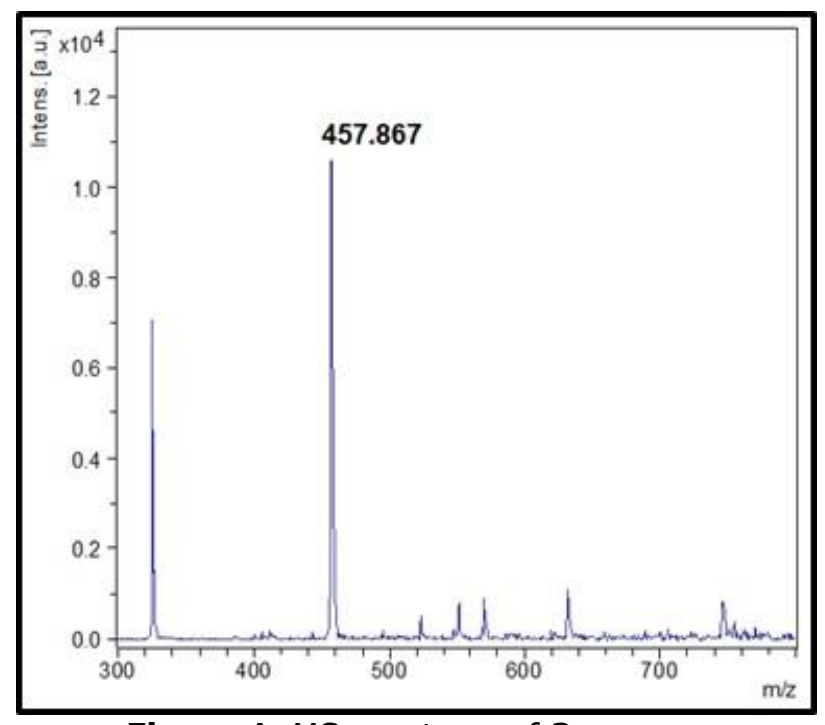

Figure 1. MS spectrum of $\mathbf{2}$.

\section{X-ray crystallography}

Data reduction was carried out using X-RED (13) while data collection and cell refinements were applied using X-AREA (13). SHELXT program (14) was used to solve molecular structure by direct methods and SHELXL2017/1 (15) program was used to refine the structure. For the preparation of the figures, Mercury for Windows (16) was utilized. Table 1 informs about the crystallographic data and the structure refinements. The $\mathrm{H}$ atoms bounded to $\mathrm{C}$ were refined by range of $0.93-0.97 \AA$.

Figure 2 illustrates the asymmetric unit of $\mathrm{C}_{30} \mathrm{H}_{36} \mathrm{~N}_{2} \mathrm{O}_{2}$ that includes one independent molecule. The $\mathrm{O}-\mathrm{H} \cdots \mathrm{N}$ intramolecular hydrogen bonds stabilize the molecular structure (Table 2 and Figure 3). The layers are also attached to each other by weak $\mathrm{C}-\mathrm{H} \cdots \Pi$ coactions to create 3D supramolecular architecture. The interaction geometry is characterized with the $\mathrm{H} \cdots \mathrm{Cg}$ length of $2.77 \AA$ with $\mathrm{C} 28-\mathrm{H} 28 \mathrm{C} \cdots \mathrm{Cg} 1^{\mathrm{i}}$ (Cg1: C5-C10 ring) angle of $172^{\circ}$. The $\mathrm{C} 13-\mathrm{C} 18$ ring is sloped to C5-C10 ring by 40.6 (7) ${ }^{\circ}$ and to C20-C25 ring by $14.3(13)^{\circ}$. According to this analysis, $\mathrm{C}_{30} \mathrm{H}_{36} \mathrm{~N}_{2} \mathrm{O}_{2}$ molecule consists in the phenolimine form (Figure 1 ). It indicates $\mathrm{O}-\mathrm{H} \cdots \mathrm{N}$ hydrogen bonding, that creates $S(6)$ ring (Table 2 and Figure 1 ). The both of C10-O1 and C25-O2 bond distances (1.345 (3) $\AA$ ) are single bonds with supporting phenol-imine form. The $\mathrm{C}-\mathrm{O}$ bond distances are obtained at lower value compared with literature data (1.354 (4) $\AA$ and 1.351 (4) $\AA$ ) (9). These bond lengths were calculated as $1.3452 \AA$ by DFT method. 


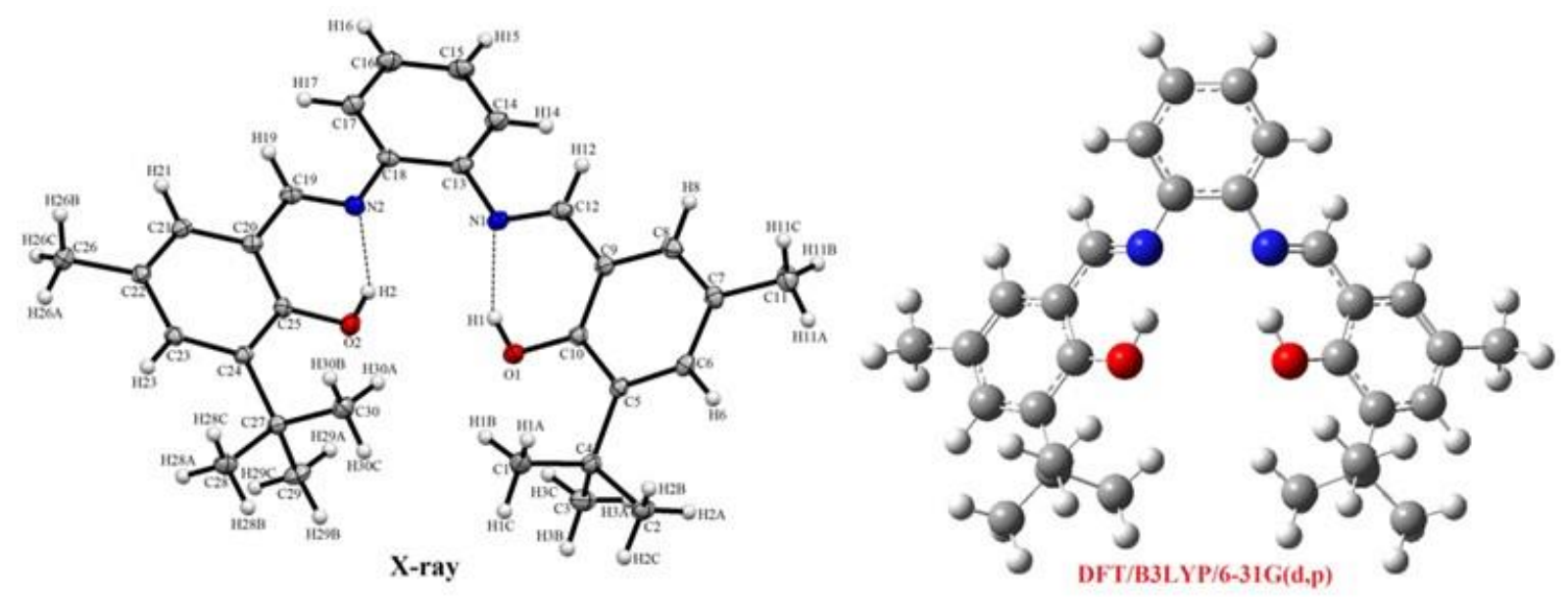

Figure 2. The molecular structures of $\mathrm{C}_{30} \mathrm{H}_{36} \mathrm{~N}_{2} \mathrm{O}_{2}$ obtained from $X$-ray and DFT.

Table 1. Some parameters for $\mathrm{C}_{30} \mathrm{H}_{36} \mathrm{~N}_{2} \mathrm{O}_{2}$ crystal.

\begin{tabular}{|c|c|}
\hline \multicolumn{2}{|l|}{ Crystal Data } \\
\hline Chemical Formula & $\mathrm{C}_{30} \mathrm{H}_{36} \mathrm{~N}_{2} \mathrm{O}_{2}$ \\
\hline Formula weight (amu) & 456.61 \\
\hline Temperature $(\mathrm{K})$ & 296 \\
\hline Crystal system & Triclinic \\
\hline Space group & P-1 \\
\hline \multicolumn{2}{|l|}{ Unit cell parameters } \\
\hline$a \neq b \neq c(\AA)$ & $\begin{array}{l}10.6074(11), 11.4195(11), 12.2383 \\
(12)\end{array}$ \\
\hline$a \neq \beta \neq Y\left({ }^{\circ}\right)$ & $71.938(7), 73.420(8), 72.881(8)$ \\
\hline Crystal size (mm) & $0.69 \times 0.47 \times 0.19$ \\
\hline Volume, $v\left(\AA^{3}\right)$ & $1315.9(2)$ \\
\hline Z & 2 \\
\hline$\mu\left(\mathrm{mm}^{-1}\right)$ & 0.07 \\
\hline $\mathrm{F}_{000}$ & 492 \\
\hline Calculated density $\left(\mathrm{mg} / \mathrm{m}^{3}\right)$ & 1.152 \\
\hline \multicolumn{2}{|l|}{ Data collection } \\
\hline Diffractometer & STOE IPDS 2 \\
\hline Wavelength $(\AA)$ & 0.71073 \\
\hline$\theta$ range for data collection $\left({ }^{\circ}\right)$ & $2.3 \leq \theta \leq 28.3$ \\
\hline \multicolumn{2}{|l|}{ Index ranges } \\
\hline$h_{\min }, h_{\max } / k_{\min }, k_{\max } / I_{\min }, I_{\max }$ & $-13,13 /-14,13 /-15,14$ \\
\hline Measurement method & $\omega$ scan \\
\hline Reflections collected & 11521 \\
\hline Independent reflections & 5158 \\
\hline Observed reflections $(\mathrm{I}>2 \sigma(\mathrm{I}))$ & 2561 \\
\hline Absorption correction & Integration \\
\hline $\mathrm{T}_{\min }, \mathrm{T}_{\max }$ & $0.967,0.990$ \\
\hline $\mathrm{R}_{\text {int }}$ & 0.047 \\
\hline \multicolumn{2}{|l|}{ Refinement } \\
\hline Refinement method & SHELXL17/1 \\
\hline Parameters & 309 \\
\hline$R\left(F^{2}>2 \sigma\left(F^{2}\right)\right)$ & 0.051 \\
\hline$w R\left(F^{2}\right)$ & 0.145 \\
\hline $\mathrm{GooF}=\mathrm{S}$ & 0.92 \\
\hline$\Delta \rho_{\min }, \Delta \rho_{\max }\left(\mathrm{e} / \AA^{3}\right)$ & $-0.13,0.20$ \\
\hline
\end{tabular}

Table 2. Hydrogen-bonds for $\mathrm{C}_{30} \mathrm{H}_{36} \mathrm{~N}_{2} \mathrm{O}_{2}$.

\begin{tabular}{lllll}
\hline \hline$D-\mathrm{H} \cdots \mathrm{A}$ & $D-\mathrm{H}(\AA)$ & $\mathrm{H} \cdots \mathrm{A}(\AA)$ & $D \cdots A(\AA)$ & $D-\mathrm{H} \cdots \mathrm{A}\left({ }^{\circ}\right)$ \\
\hline \hline $\mathrm{O} 1-\mathrm{H} 1 \cdots \mathrm{N} 1$ & 0.82 & 1.87 & $2.613(2)$ & 149
\end{tabular}




$\begin{array}{lllll}\mathrm{O} 2-\mathrm{H} 2 \cdots \mathrm{N} 2 & 0.82 & 1.88 & 2.612(2) & 148 \\ \mathrm{C} 28-\mathrm{H} 28 \mathrm{C} \cdots \mathrm{Cg} 1^{\mathrm{i}} & 0.96 & 2.77 & 3.7193 & 172\end{array}$

Symmetry code: (i) $-x+1,-y+1,-z+1$.

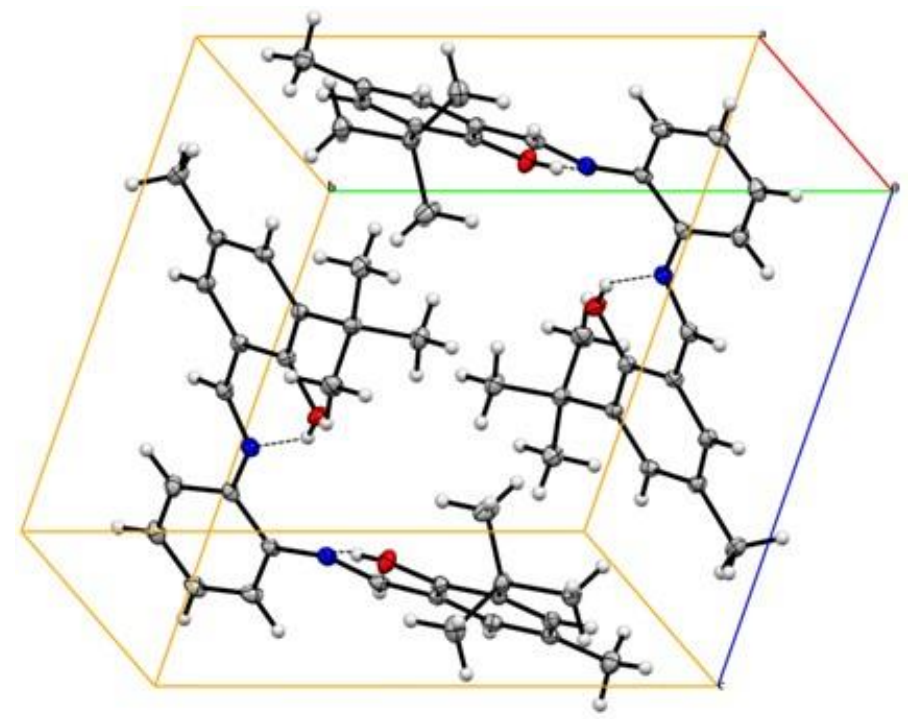

Figure 3. $A$ view of packing of $\mathrm{C}_{30} \mathrm{H}_{36} \mathrm{~N}_{2} \mathrm{O}_{2}$ with $\mathrm{O}-\mathrm{H} \cdots \mathrm{N}$ hydrogen bond interactions.

Table 3. Some geometric parameters of $\mathrm{C}_{30} \mathrm{H}_{36} \mathrm{~N}_{2} \mathrm{O}_{2}\left(\AA^{\circ}{ }^{\circ}\right)$.

\begin{tabular}{lll}
\hline Bonds & X-ray & DFT/B3LYP/6-31G(d,p) \\
\hline \hline C10-O1 & $1.345(3)$ & 1.3452 \\
$\mathrm{C} 25-\mathrm{O} 2$ & $1.345(3)$ & 1.3452 \\
$\mathrm{~N} 1-\mathrm{C} 12$ & $1.278(3)$ & 1.2744 \\
$\mathrm{~N} 1-\mathrm{C} 13$ & $1.408(3)$ & 1.4075 \\
$\mathrm{~N} 2-\mathrm{C} 18$ & $1.407(3)$ & 1.4071 \\
$\mathrm{~N} 2-\mathrm{C} 19$ & $1.275(3)$ & 1.2786 \\
$\mathrm{O} 1-\mathrm{C} 9-\mathrm{C} 10$ & $120.3(2)$ & 120.229 \\
$\mathrm{O} 2-\mathrm{C} 25-\mathrm{C} 20$ & $120.2(2)$ & 120.288 \\
$\mathrm{C} 12-\mathrm{N} 1-\mathrm{C} 13$ & $120.1(2)$ & 120.068 \\
$\mathrm{C} 18-\mathrm{N} 2-\mathrm{C} 19$ & $121.6(2)$ & 121.655 \\
\hline
\end{tabular}

\section{DFT calculations}

Gaussian03 software (17) was utilized to obtain the molecular geometry optimization of $\mathrm{C}_{30} \mathrm{H}_{36} \mathrm{~N}_{2} \mathrm{O}_{2}$ and Gauss-View4.1 (18) software was utilized to visualize the calculation results. For $\mathrm{C}_{30} \mathrm{H}_{36} \mathrm{~N}_{2} \mathrm{O}_{2}$, theoretical calculations were carried out at B3LYP/6-31G(d,p) level. Table 3 informs some structural parameters getting from the DFT method for $\mathrm{C}_{30} \mathrm{H}_{36} \mathrm{~N}_{2} \mathrm{O}_{2}$ with experimental results. The optimized geometric parameters are in a good accordance with the empirical results. Figure 2 illustrates the optimized structure of $\mathrm{C}_{30} \mathrm{H}_{36} \mathrm{~N}_{2} \mathrm{O}_{2}$. The theoretical results were found to be a little distinct from empirical data. This difference is due to consideration of the molecule in the gas phase for computations. Because in the gas phase, the molecules do not interact between each other. Figure 4 shows that the experimental geometries obtained from X-ray diffraction and theoretically obtained geometries were overlapped. RMSE value was calculated as $0.405 \AA$. This result informs that the optimized geometry is in a good accordance with the experimental structure. 


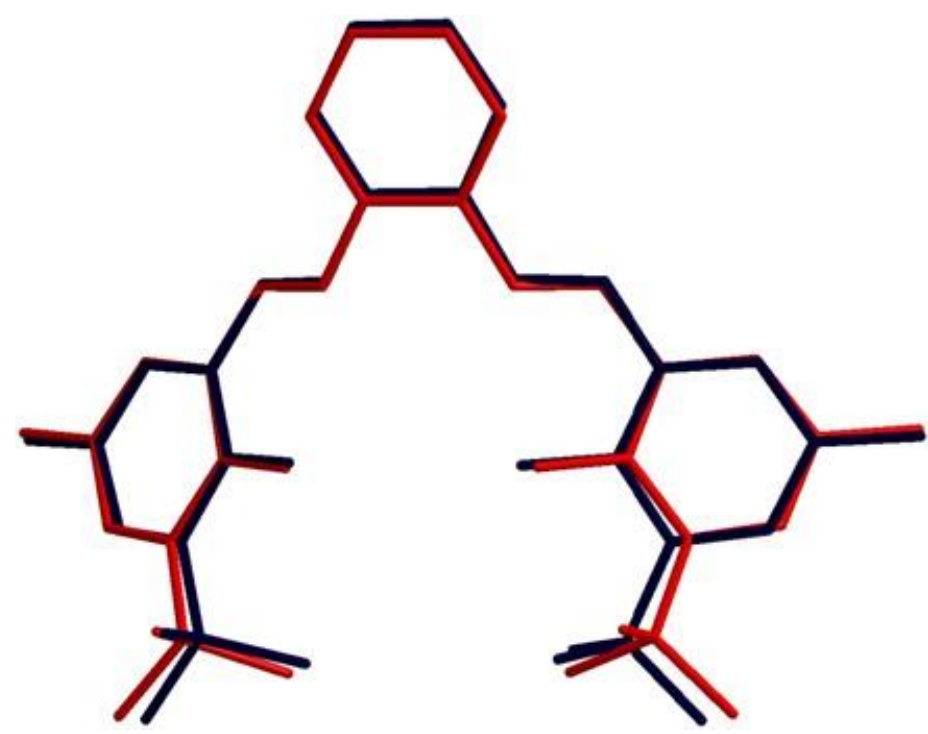

Figure 4. A molecular accordance of the empirical and computed structures given in black and red, respectively. Hydrogen atoms were excluded for clarity.

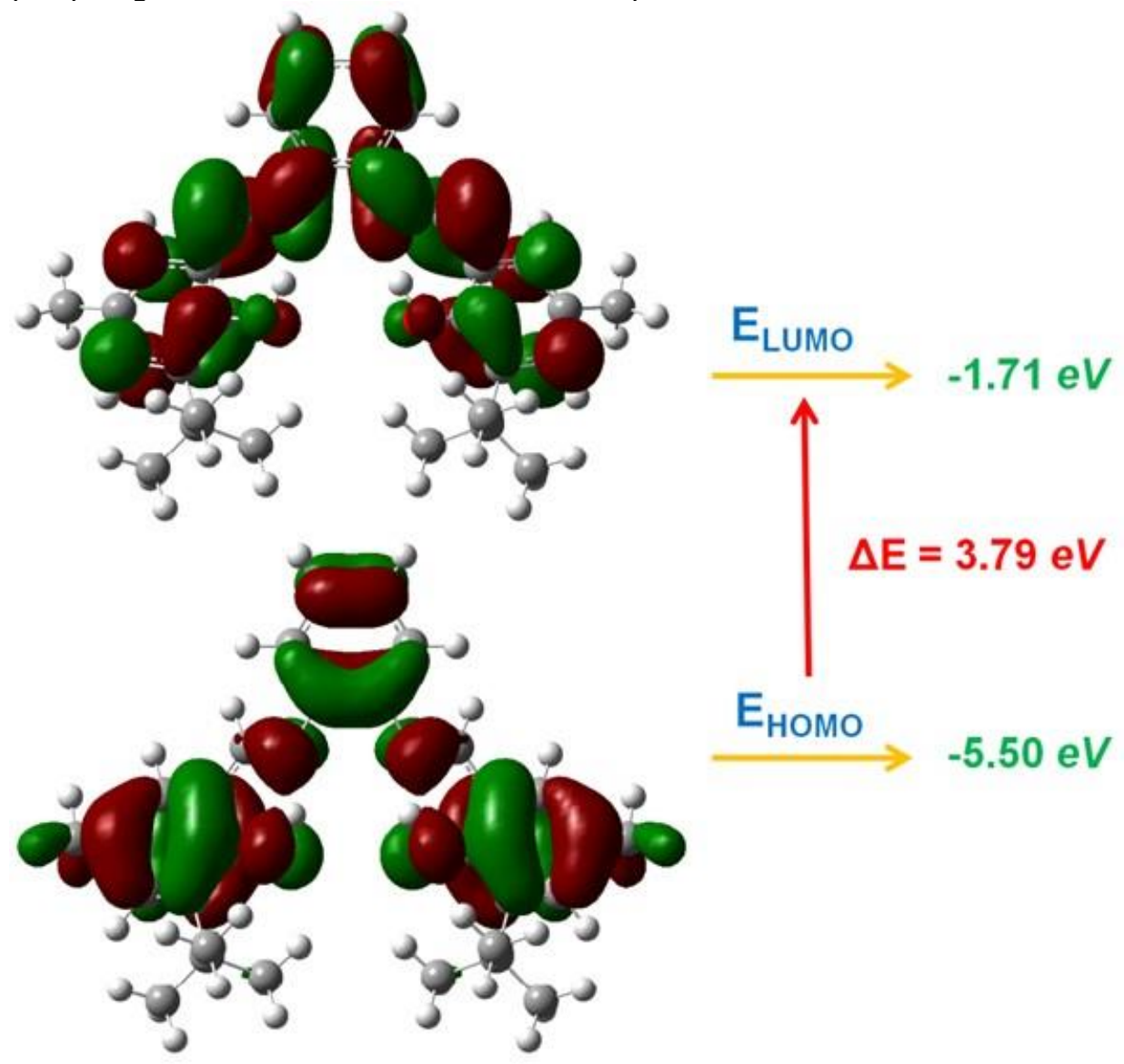

Figure 5. HOMO and LUMO plots of $\mathrm{C}_{30} \mathrm{H}_{36} \mathrm{~N}_{2} \mathrm{O}_{2}$ for DFT method and B3LYP/6-31G(d,p) level.

The highest occupied molecular orbital (HOMO) and lowest unoccupied molecular orbital (LUMO) orbitals are described as the frontier molecular orbitals. HOMO-LUMO energy separation has been used as a simple indicator of kinetic stability. A large HOMOLUMO gap implies high kinetic stability and low chemical reactivity (19). Figure 5 shows the distributions of HOMO and LUMO orbitals calculated by the DFT method and at B3LYP/6$31 \mathrm{G}(d, p)$ level for of $\mathrm{C}_{30} \mathrm{H}_{36} \mathrm{~N}_{2} \mathrm{O}_{2}$. The HOMOLUMO energy gap was found as $3.79 \mathrm{eV}$. Therefore, this result informs us that the molecular structure of $\mathrm{C}_{30} \mathrm{H}_{36} \mathrm{~N}_{2} \mathrm{O}_{2}$ is stable. 


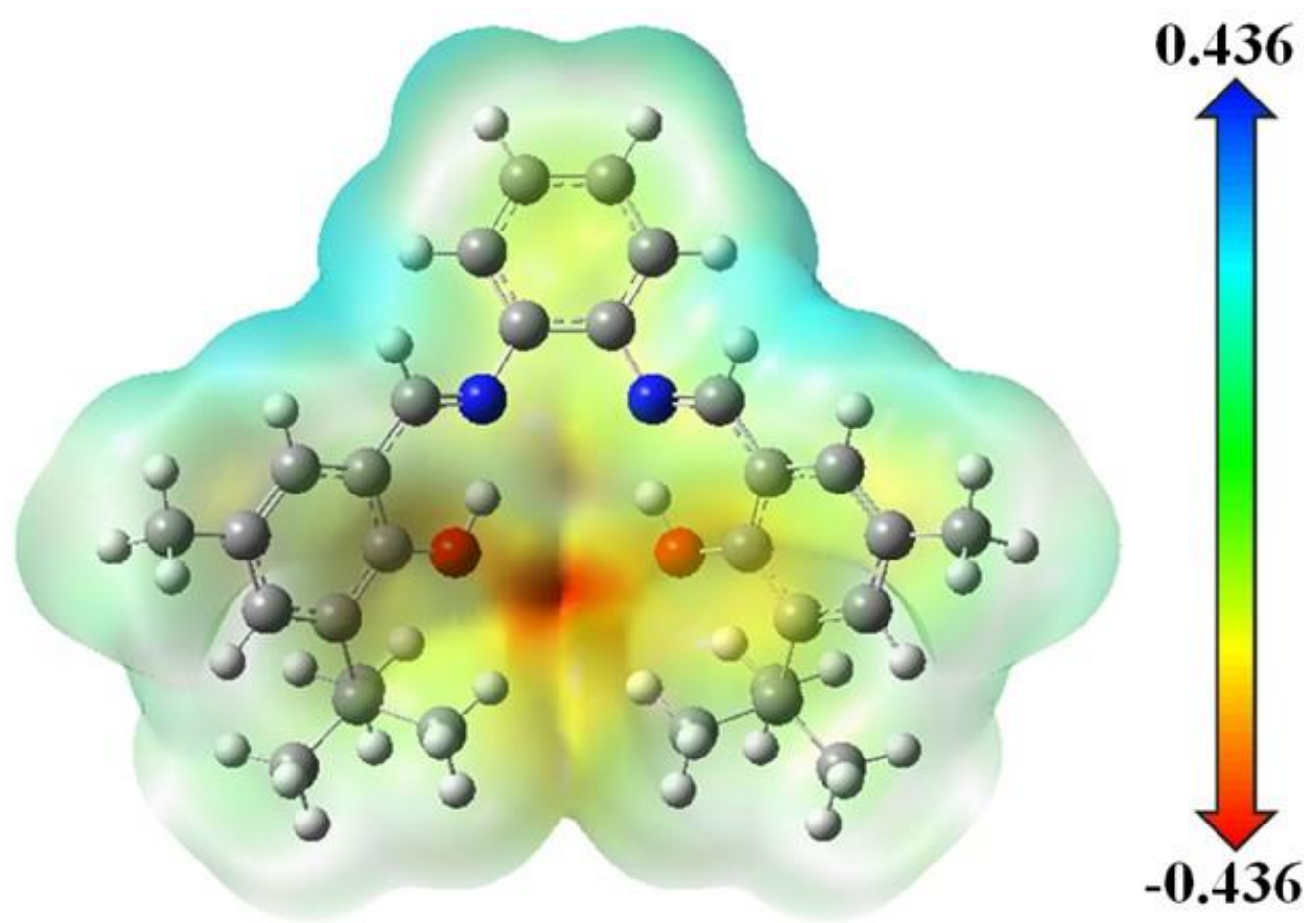

Figure 6. The MEP surface of $\mathrm{C}_{30} \mathrm{H}_{36} \mathrm{~N}_{2} \mathrm{O}_{2}$ for DFT method and $B 3 L Y P / 6-31 G(d, p)$ level.

One can understand from the graph of MEP surface that positive potential sites are on the hydrogen atoms as well as negative potential sites are on the electronegative atoms (2025). For intermolecular and intramolecular hydrogen bonding, these regions give information about possible interactions. The graph of MEP surface calculated by the DFT method and at B3LYP/6-31G(d,p) level. Figure 6 shows that the blue regions are radiated over $\mathrm{H}$ atoms and negative regions are radiated over $\mathrm{O}$ atoms. Negative regions are mostly above $\mathrm{O} 1$ and $\mathrm{O} 2$. According to these results, one can obtain information about the regions where the compound may have intramolecular interaction. Thus, the intramolecular hydrogen bonds in Table 2 were confirmed by Figure 6.

\section{Hirshfeld surface analysis}

The Crystal Explorer software (26) was utilized to analyze the Hirshfeld surface. For specifying the diverse intermolecular interactions in $\mathrm{C}_{30} \mathrm{H}_{36} \mathrm{~N}_{2} \mathrm{O}_{2}$ compound, Hirshfeld surfaces and related 2D fingerprint plots were obtained. Figure 7 illustrates Hirshfeld surfaces of $\mathrm{C}_{30} \mathrm{H}_{36} \mathrm{~N}_{2} \mathrm{O}_{2}$ with mapped $d_{\text {norm, }}, d_{i}$ and $d_{e}$. The red spots over Hirshfeld surface point out the inter-contacts included in hydrogen bonds (27-31). The surfaces of 3D $d_{\text {norm }}$ plotted with a color scale of -0.103 to $1.501 \AA$ with a standard (high) surface resolution.
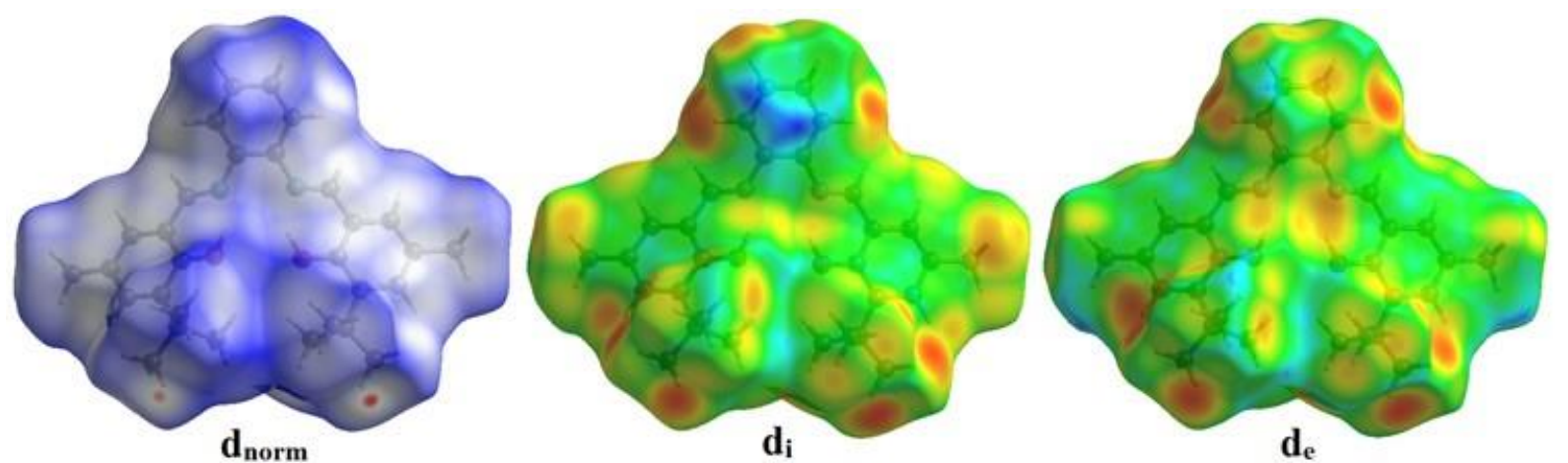

Figure 7. The Hirshfeld surface of $\mathrm{C}_{30} \mathrm{H}_{36} \mathrm{~N}_{2} \mathrm{O}_{2}$ plotted with $d_{n o r m}, d_{i}$ and $d_{e}$. 


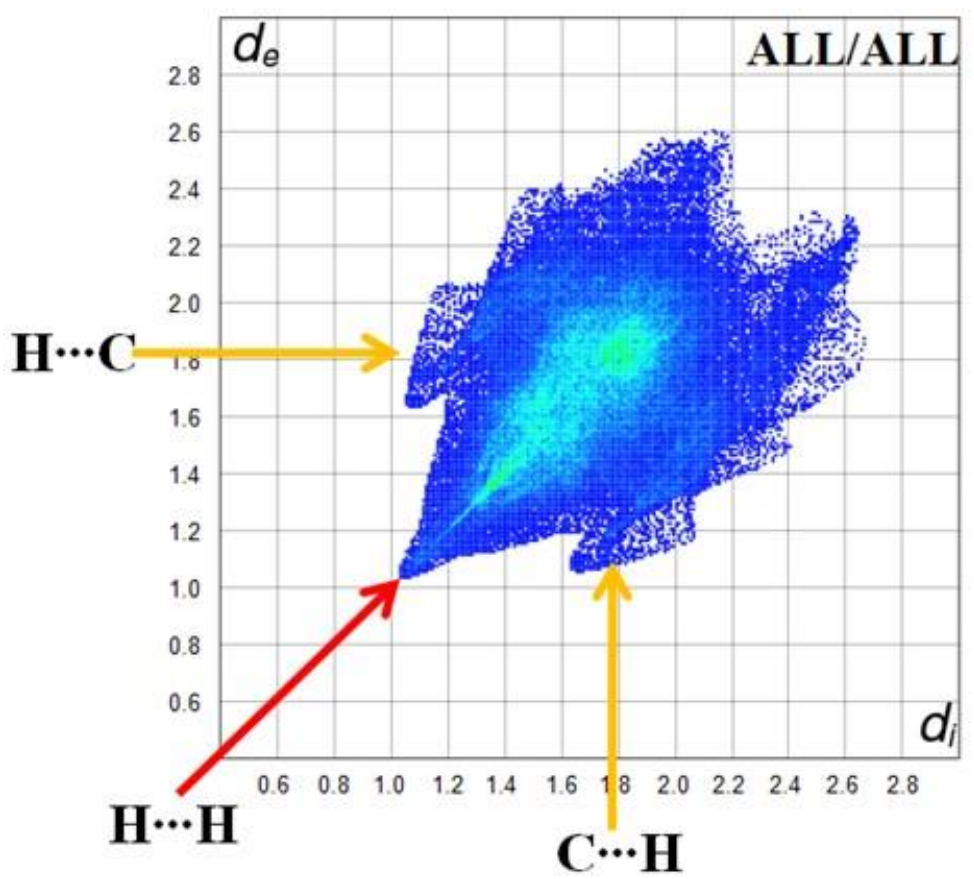

Figure 8. The fingerprint of $\mathrm{C}_{30} \mathrm{H}_{36} \mathrm{~N}_{2} \mathrm{O}_{2}$.

Figure 8 shows the two-dimensional fingerprint of the sum of the contacts contributing to the Hirshfeld surface indicated in normal mode. Figure $9 a(\mathrm{H} \cdots \mathrm{H})$ graph illustrates the 2D fingerprint of $\left(d_{i}, d_{e}\right)$ points related to $\mathrm{H}$ atoms. It is pointed out an end point which makes a sign to the beginning and fits to $d_{i}=d_{e}=1.08 \AA$, which represents existence of $\mathrm{H} \cdots \mathrm{H}$ contacts in $\mathrm{C}_{30} \mathrm{H}_{36} \mathrm{~N}_{2} \mathrm{O}_{2}$ molecule (71.2\%). In Figure 9b, two symmetrical wings on left and right sides $(18.7 \%)$ are shown on the graph of $\mathrm{H} \cdots \mathrm{C} / \mathrm{C} \cdots \mathrm{H}$ interactions. Furthermore, there are $\mathrm{C} \cdots \mathrm{C}$ $(4.8 \%)$ and $\mathrm{H} \cdots \mathrm{N} / \mathrm{N} \cdots \mathrm{H}(2.7 \%)$ contacts. 

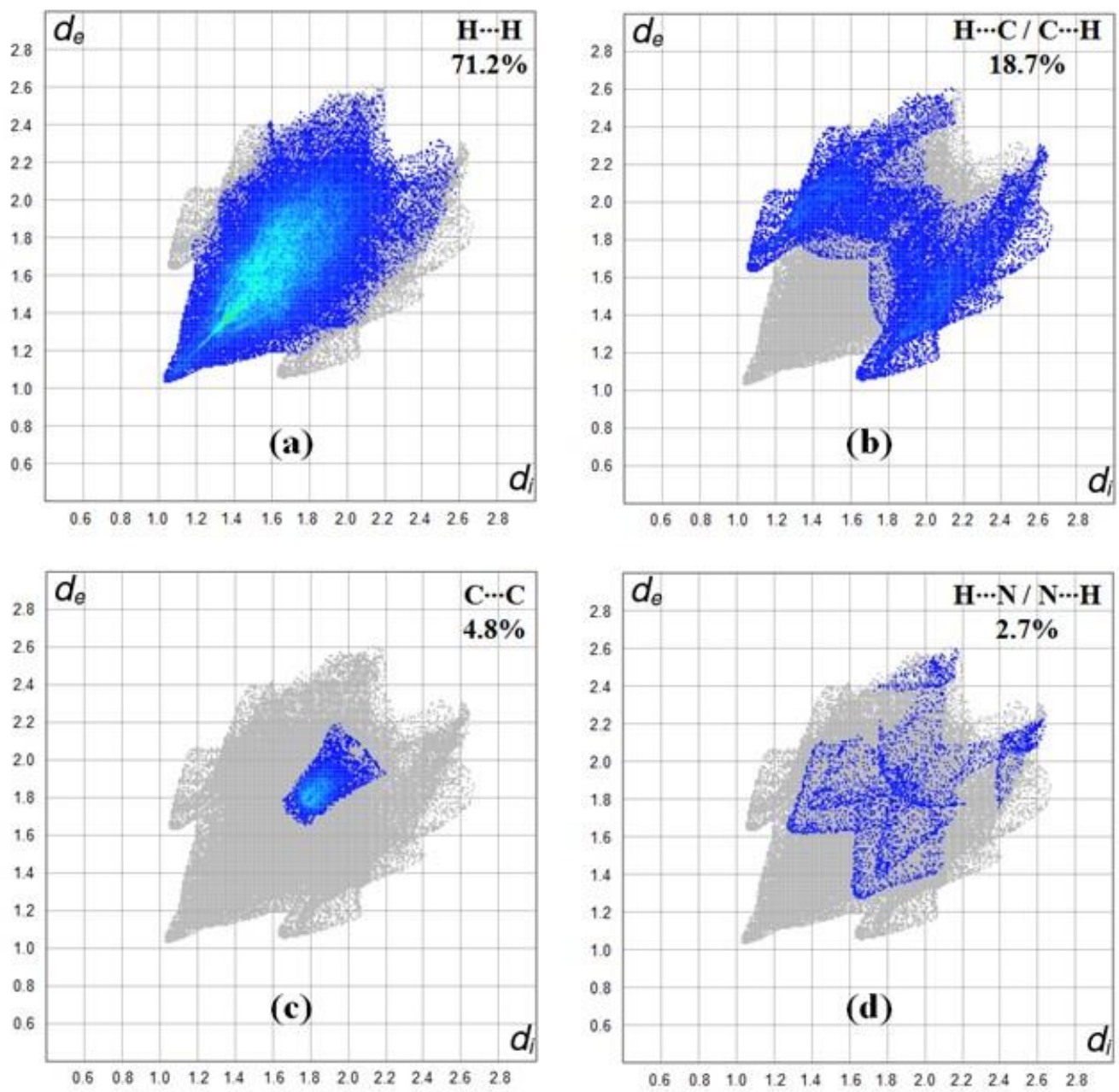

Figure 9. A perspective of 2D fingerprint plots with a $d_{\text {norm }}$ for (a) $\mathrm{H} \cdots \mathrm{H}(71.2 \%)$, (b) $\mathrm{H} \cdots \mathrm{C} / \mathrm{C} \cdots \mathrm{H}$ $(18.7 \%),(c) \mathrm{C} \cdots \mathrm{C}(4.8 \%)$ and (d) $\mathrm{H} \cdots \mathrm{N} / \mathrm{N} \cdots \mathrm{H}(2.7 \%)$ contacts in $\mathrm{C}_{30} \mathrm{H}_{36} \mathrm{~N}_{2} \mathrm{O}_{2}$.

Figure 10 illustrates the view of the molecular electrostatic potential surface that plotted over three-dimensional Hirshfeld surface of $\mathrm{C}_{30} \mathrm{H}_{36} \mathrm{~N}_{2} \mathrm{O}_{2}$ utilizing DFT/B3LYP level of theory with $6-31 G(d, p)$ basis set in the range -0.035 to 0.042 a.u.. In Figure 10, the blue and red regions over the atoms associated with positive and negative molecular electrostatic potentials are represented as the donors and acceptors, respectively. 


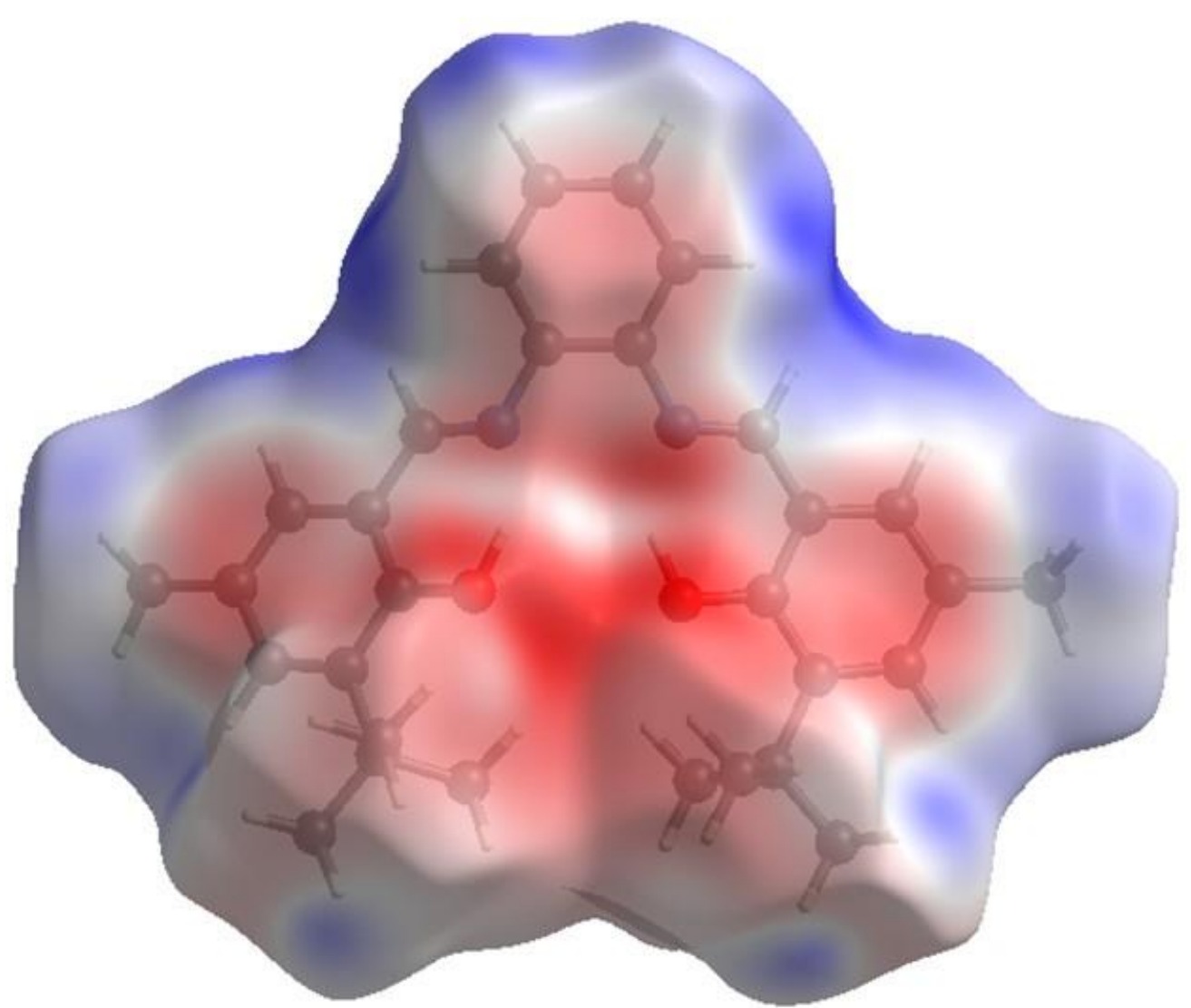

Figure 10. The molecular electrostatic potential surface of $\mathrm{C}_{30} \mathrm{H}_{36} \mathrm{~N}_{2} \mathrm{O}_{2}$.

\section{CONCLUSION}

In this paper, N,N'-bis(3-tert-butyl-5methylsalicylidene) -1,2-diaminophenylene (2) has been synthesized and characterized by the common spectroscopic methods. The final product was attained as single crystals suitable for $\mathrm{X}$-ray results. In the gas phase, the molecules do not interact between each other for the DFT calculations. Molecular electrostatic potential (MEP) map gives information about the negative sites being intensified mostly over $\mathrm{O} 1$ and $\mathrm{O} 2$ atoms. Hirshfeld surface analysis determining the diverse intermolecular interactions in $\mathrm{C}_{30} \mathrm{H}_{36} \mathrm{~N}_{2} \mathrm{O}_{2}$ molecule provides the hydrogenbond donor and hydrogen-bond acceptor areas.

\section{REFERENCES}

1. Schiff $H$. Mittheilungen aus dem Universitätslaboratorium in Pisa: Eine neue Reihe organischer Basen. Justus Liebigs Annalen der Chemie. 1864;131:118-9.

2. Arulmurugan S, Kavitha HP, Venkatraman BR. Biological activities of Schiff base and its complexes: a review. Rasayan J. Chem, 2010;3:385-410.

3. Behpour M, Ghoreishi SM, Mohammadi N, Soltani N, Salavati-Niasari M. Investigation of some Schiff base compounds containing disulfide bond as $\mathrm{HCl}$ corrosion inhibitors for mild steel. Corros. Sci. 2010;52:4046-57.

4. Cozzi PG. Metal-Salen Schiff base complexes in catalysis: practical aspects. Chem. Soc. Rev. 2004;33:410-21.

5. Anis I, Aslam M, Noreen Z, Afza N, Hussain A, Safder M, Chaudhry AH. A Review (part a)General Applications of Schiff Base Transition Metal Complexes. Int. J. Cur. Pharm. Res. 2013;5:21-4.

6. Gupta KC, Sutar AK. Catalytic activities of Schiff base transition metal complexes. Coord. Chem. Rev. 2008;252:1420-50.

7. Anis I, Aslam M, Afza N, Iqbal L, Noreen Z, Hussain A, Safder M. A review (part c)-an overview of biological activities of schiff base transition metal complexes. Int. J. Cur. Pharm. Res. 2013;5:48-57.

8. Kumar S, Nath DD, Saxena PN. Applications of metal complexes of Schiff bases-A Review. J. Sci. Ind. Res. 2009;68:181-7.

9. Dekar S, Ouari K, Bendia S, Hannachi D, Weiss J. Mononuclear oxovanadium(IV) Schiff base complex: Synthesis, spectroscopy, electrochemistry, DFT calculation and catalytic 
activity. J. of Organometal. Chem. 2018;866:165-76.

10. Ding R, Wang Q, Wen X. 6,6-Di-tert-butyl4,4-dimethyl-2,2-(1,2-

phenylenebis(nitrilomethanylylidene))

Diphenol. Acta Cryst. 2012;E68:40.

11. Perrin DD, Armarego WLF, Perrin DR. Purification of Laboratory Chemicals. Pergamon Press, New York;2013.

12. Larrow JF, Jacobsen EN. A Practical Method for the Large-Scale Preparation of $\left(\mathrm{N}, \mathrm{N}^{\prime}-\right.$ Bis(3,5-di-tertbutylsalicylidene)-1,2cyclohexanediaminato(2-))manganese(III) chloride, a Highly Enantioselective Epoxidation Catalyst. J. Org. Chem. 1994;59:1939-42.

13. Stoe and Cie. X-AREA and X-RED32. Stoe \& Cie, Darmstadt, Germany, 2002.

14. Sheldrick GM. SHELXT - Integrated spacegroup and crystal-structure determination. Acta Cryst. 2015;A71:3-8.

15. Sheldrick GM. Crystal structure refinement with SHELXL. Acta Cryst. 2015;C71:3-8.

16. Macrae $C F$, Edgington $P R$, McCabe $P$, Pidcock E, Shields GP, Taylor R, Towler M, Streek J. Mercury: visualization and analysis of crystal structures. J. Appl. Cryst. 2006;39:453-7.

17. Farrugia LJ. WinGX and ORTEP for Windows: an update. J. Appl. Cryst. 2012;32:837.

18. Frisch $M J$, Trucks GW, Schlegel $H B$, Scuseria GE, Robb MA, Cheeseman JR, Montgomery JA, Vreven T, Kudin KN, Burant JC, Millam JM, Iyengar SS, Tomasi J, Barone V, Mennucci B, Cossi M, Scalmani G, Rega N, Petersson GA, Nakatsuji $H$, Hada $M$, Ehara $M$, Toyota K, Fukuda R, Hasegawa J, Ishida M, Nakajima T, Honda Y, Kitao O, Nakai H, Klene $M$, Li X, Knox JE, Hratchian HP, Cross JB, Bakken V, Adamo C, Jaramillo J, Gomperts R, Stratmann RE, Yazyev O, Austin AJ, Cammi R, Pomelli C, Ochterski JW, Ayala PY, Morokuma $K$, Voth GA, Salvador P, Dannenberg JJ, Zakrzewski VG, Dapprich S, Daniels AD, Strain MC, Farkas O, Malick DK, Rabuck AD, Raghavachari K, Foresman JB, Ortiz JV, Cui Q, Baboul AG, Clifford S, Cioslowski J, Stefanov BB, Liu G, Liashenko A, Piskorz P, Komaromi I, Martin RL, Fox DJ, Keith T, Al-Laham MA, Peng CY, Nanayakkara A, Challacombe M, Gill PMW, Johnson B, Chen W, Wong MW, Gonzalez C, Pople JA. Gaussian 03, Revision E.01, Gaussian, Inc., Wallingford;2004.
19. Aihara, J-i. Reduced HOMO-LUMO Gap as an Index of Kinetic Stability for Polycyclic Aromatic Hydrocarbons. J. Phys. Chem. A $1999 ; 103: 7487-95$.

20. Demircioglu Z, Albayrak C, Buyukgungor O. Experimental (X-ray, FT-IR and UV-vis spectra) and theoretical methods (DFT study) of (E)-3-methoxy-2-((p-tolylimino) methyl) phenol. Spect. Acta. Part A, 2014;128:74858.

21. Ersanli CC, Kantar GK, Şaşmaz S. Crystallographic, spectroscopic (FTIR and NMR) and quantum computational calculation studies on bis(2-methoxy-4-((E)-prop-1enyl)phenyl)oxalate. J. Mol. Struct. 2017;1143: 318-27.

22. Asiri AM, Ersanlı CC, Şahin O, Arshad MN, Hameed SA. Molecular structure, spectroscopic and quantum chemical studies of $1^{\prime}, 3^{\prime}, 3^{\prime}$-trimethylspiro(benzo(f)chromene3,2'-indoline. J. Mol. Struct. 2016;1111:10817.

23. Kansız S, Dege N. Synthesis, crystallographic structure, DFT calculations and Hirshfeld surface analysis of a fumarate bridged $\mathrm{Co}$ (II) coordination polymer. J. Mol. Struct. 2018;1173:42-51.

24. Gümüş MK, Kansız S, Aydemir E, Gorobets NY, Dege N. Structural features of 7-methoxy5-methyl-2-(pyridin-3-yl)-11,12-dihydro-

5,11-methano $(1,2,4)$ triazolo $(1,5-$

c) $(1,3,5)$ benzoxadiazocine: Experimental and theoretical (HF and DFT) studies, surface properties (MEP, Hirshfeld). J. Mol. Struct. 2018;1168:280-90.

25. Sen F, Kansiz S, Ucar I. A one-dimensional copper(II) coordination polymer incorporating succinate and N,Ndi-ethyl-ethyl-ene-di-amine ligands: crystallographic analysis, vibrational and surface features, and DFT analysis. Acta Cryst. 2017;C73:517-5242017.

26. Turner MJ, MacKinnon JJ, Wolff SK, Grimwood DJ, Spackman PR, Jayatilaka D, Spackma MA. Crystal Explorer Ver. 17.5. University of Western Australia, Perth;2017.

27. Kansiz S, Malinkin S, Dege N. Synthesis, Crystal structure and Hirshfeld surface analysis of tetraaquabis(isonicotinamideKN1)cobalt(II) succinate. Acta Cryst. 2018;E74:1026-29.

28. Kansiz S, Almarhoon ZM, Dege N. Synthesis, crystal structure and Hirshfeld surface analysis of tetraaquabis 
(isonicotinamide-kN1) cobalt (II) fumarate. Acta Cryst. 2018;E74:217-20.

29. Aydemir E, Kansiz S, Gumus MK, Gorobets NY, Dege N. Crystal structure and Hirshfeld surface analysis of 7-ethoxy-5-methyl-2(pyridin-3-yl)-11, 12-dihydro-5, 11-methano $(1,2,4)$ triazolo $(1,5-c)(1,3,5)$ benzoxadiazocine. Acta Cryst. 2018;E74:36770.
30. Sen P, Kansiz S, Dege N, Iskenderov TS, Yildiz SZ. Crystal structure and Hirshfeld surface analysis of $4-(4-(1 \mathrm{H}-$ benzo(d)imidazol-2-yl)phenoxy)phthalonitrile monohydrate Acta Cryst. 2018;E74:994-7.

31. Sen P, Kansiz S, Golenya IA, Dege N. Crystal structure and Hirshfeld surface analysis of N, N'-bis (3-tert-butyl-2-hydroxy5-methylbenzylidene) ethane-1, 2-diamine. Acta Cryst. 2018;E74:1147-50. 